\title{
妊娠子宮が及ぼす大網膜の変化によ る乳牛の内蔵変位症候群について
}

\author{
村山共同家畜揨療所 \\ 佐藤彪・清野哲夫・五十嵐哲雄・中野和光 \\ 佐藤 緑・伊藤礼子・佐藤修一・清野頃吾
}

はじめに

近年, 内蔵変位などの消化器知患が特に分娩直後の乳牛に多発し, 年々漸增の傾向を示している。赤松 (1)は分婏後60日以内に発症したもの65\%，2 週間以内に発生したもの40\%，宮原ら(2)は1 か月以内に発 病が多く、森ら(3)も全症例の半数を越え，妊娠後半の子宮重量と，分婏のストレスが密接な関係がある 之祱明L,WHITELOCK.R.H.（1969)(4)は分娩後 4 週間以内に $80 \%$ 発症を認めている。更に今後多 発の傾向にあることを示している。

我々は以前から，妊娠子宮が大網膜の内部に腸と共に包藏されているため, 大網膜は子宮の鼔大の経 過につれて弛緩し，脂肪が蓄積し網膜層が厚くなり，第一胃は前上方におし上げられ，腸の場所が失わ れて, 圧迫されたり, 網膜外に移動が起り, 分婏後も移動した腸や, 弛緩して前方に移動した網膜が元 に復しきれず，内臓変位という症候群が形成されるのではないかと疑念をもち検討を重ねているうちに， 興味ある症例に遭遇したので報告し，御批判を仰ぎたいと思う。

\section{症例並びにその所見について}

1. 変位症候群の症例 炤和 50 年より変位症候群として診療した第四胃左方・右方変位, 晹変位, 盲腸 便秘，捻転，更に脂肪壊死症の年度別発生を第 1 表に示した。炤和50年に 6 頭発生して 3 頭治瘳し， 3 頭か廃用になった。昭和51年から漸増し，54年は13頭が発生し，治癒11頭，廃用 2 頭であった。55年は 8 月までに11䫓が発生し，合計すると58頭発生し，48頭が治癒し（87.76\%），10垻が廃用となった。

表 1. 第四胃执よび腸变位, 脂肪壊死症の年度別発生頭数

\begin{tabular}{c|c|c|c}
\hline 年 度 & 発生頭 数 & 治ゆ頭 数 & 廃用頭数 \\
\hline 50 & 6 & 3 & 3 \\
51 & 7 & 7 & - \\
52 & 10 & 10 & - \\
53 & 11 & 8 & 3 \\
54 & 13 & 11 & 2 \\
55.8 & 11 & 9 & 2 \\
\hline 計 & 58 & 48 & 10 \\
\hline 比率 $(\%)$ & 100 & 82.76 & 17.24 \\
\hline
\end{tabular}

2. 症例の所見について 個体別の一般的な概要を第 2 表に示した。開腹時の所見は. 
表 2. 変位症候群の一般概要

\begin{tabular}{|c|c|c|c|c|c|c|c|}
\hline $\begin{array}{c}\text { 症例 } \\
\mathrm{Na}\end{array}$ & 病 & 生年月日 & 分娩年月日 & $\begin{array}{l}\text { 発 病 } \\
\text { 年 月 }\end{array}$ & 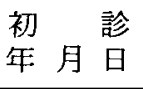 & $\begin{array}{l}\text { 手 術 } \\
\text { 年 月 }\end{array}$ & 転㷌年月日 \\
\hline $\begin{array}{c}\mathrm{A} \\
20\end{array}$ & 盲 腸 変 位 & 47. 2.27 & 妊娠 5 加月 & 52. 7. 22 & 52. 7.24 & 52. 8. 5 & 52. 8.16 治 \\
\hline $\begin{array}{r}\mathrm{B} \\
30\end{array}$ & $\begin{array}{l}\text { 第一罠泡沫性鼓脹 } \\
\text { 第四胃右方変位 }\end{array}$ & 51. 10. 24 & \begin{tabular}{crr|} 
妊 & & 娠 \\
8. & 5 加月 \\
\end{tabular} & 54.12. 5 & 54.12 .8 & 54.12 .11 & 54.12.21 治 \\
\hline $\begin{array}{l}\mathrm{C} \\
2\end{array}$ & $\begin{array}{l}\text { 第四胃右方変位 } \\
\text { 脂 肪 壊 死 }\end{array}$ & 51.4 & \begin{tabular}{lrr|r} 
妊 & 9 & 加 \\
早 & & 産 \\
\end{tabular} & 54. 4.23 & 54. 4. 29 & 54. 5. 1 & $54,5,11$ 治 \\
\hline $\begin{array}{l}\mathrm{D} \\
37\end{array}$ & 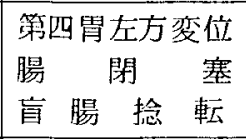 & 49. 8. & 55.4. 3 分婏 & 55. 4. 5 & 55. 4. 5 & 55. 4.10 & 55. 4.18 治 \\
\hline $\begin{array}{l}E \\
45\end{array}$ & \begin{tabular}{|lcl} 
産後起立不能 \\
脂 \\
肪 壊 & 死 \\
晹 & 閉 & 塞 \\
\end{tabular} & 48. 10. 30 & 55.3 .28 分婏 & 55. 3.28 & 55. 3.28 & - & 55. 4. 1 廃 \\
\hline $\begin{array}{l}F \\
51\end{array}$ & $\begin{array}{l}\text { 子宮脱, 起立不 } \\
\text { 能, 乳房炎, 腸 } \\
\text { 閉塞, 食道溝捻 } \\
\text { 転 }\end{array}$ & 48. 3. 27 & 55.4 .20 分婏 & 55. 4. 21 & 55. 3.21 & - & 55. 4.30 廃 \\
\hline
\end{tabular}

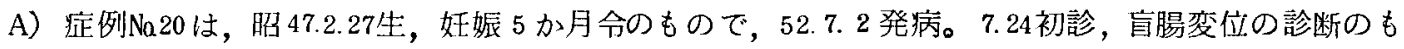
とに 8.5 開腹手術を行ったとてろ, 図1に示すような所見であった。すなわち娃娠子宮は大網蟇内にあって

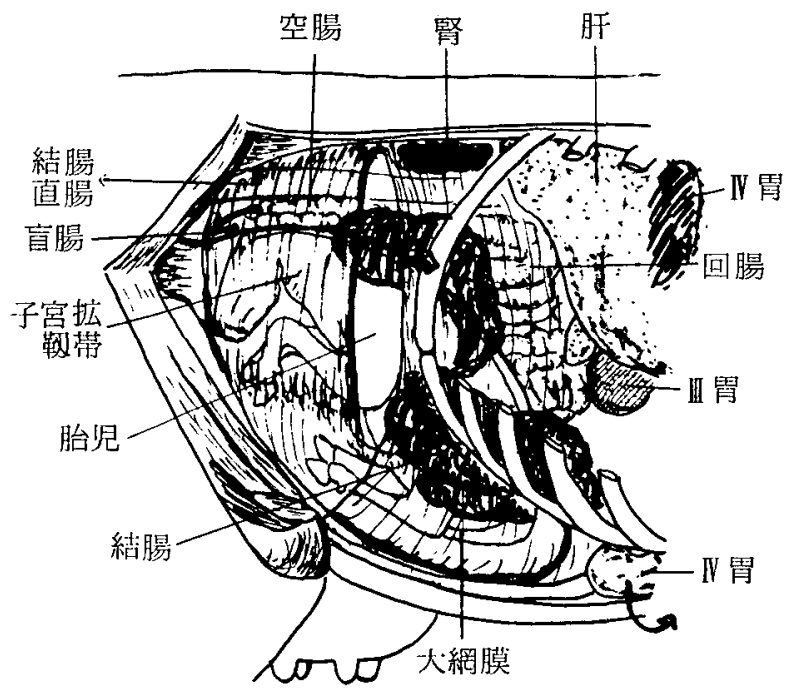

図 1. 妊娠 5 力月令の盲腸便秘の模式図 腸を压迫し，皆腸は著しく気脹膨満して左側 に変位していた。結腸は内容物が著しく停滞 して䞡満し，腹水過多にして大網膜前方に移 動し，背壁の腸間膜根部の軸転を来たし，血 行障害, 内蔵神経麻禆をもたらした变位症候 群であると解された。本症例は大網膜を子宮 から外して腸を整腹したところ，分娩も正常 に経過した。

B）症例 No.30 は昭51.10.24生。妊娠8.5 少 月令のもので, 昭 $54.12 .5 よ り$ 食欲不振であ った。12.8 初讋時, 腹囲著しく臌満し, 鼓音 発した。ガスを排除するに泡沫性鼓脹在 確恋し，一応対症療法を施したが，再発する ので開腹手術を実施したところ，以外なこと に第四胃は右方に変佂し，臌満した第四霄が 腸間膜根部に変位しているのが確認された。第一胃の内容物は, 繊維性に富んだ飼料が全くなく, 泡沫 性のガスが充填しており，冒切開と同時にビールの栓を抜いた時の泡沫の噴出と同しょうに，泡沫が噴 出したが，第四胃内のガスは，いわゆるガス状のものであった。食道溝部が軸転し鈎状に後方に回転し ており，娃娠子宮は，大網膜内部にあって大網膜は前方に移し腹水過多，腸間膜根部がやや軸転し，空 
腸は第一䡒後方下腹部より大網膜より脱出した一連の変位症候郡と考えられた。12.21治瘜の転帰をとっ たが, 分娘後右方変位が再発し, 第四鱼内は, 血液が混入した大量の水様性にして黒茶色を呈した内容 物が充满しており，第四胃切開を行ない内容物を除去したとてろ治瘾した。

C）症例 No. 2 は, 䏦51.4.生。奸娠 9 か月令で早座し, 54.4.23発病。4.29初診時, 第四胃右方変位の診 断のもとに，5.1 開腹手術を行い確認できた所見を図 2 に示した。第一胃は縮小し上方に押し上げられ， 大網膜は前方に波状䀛壁をなし，アコーデオン状に移動弛緩し空腸は大網膜外部に脱出し，大網膜と腹

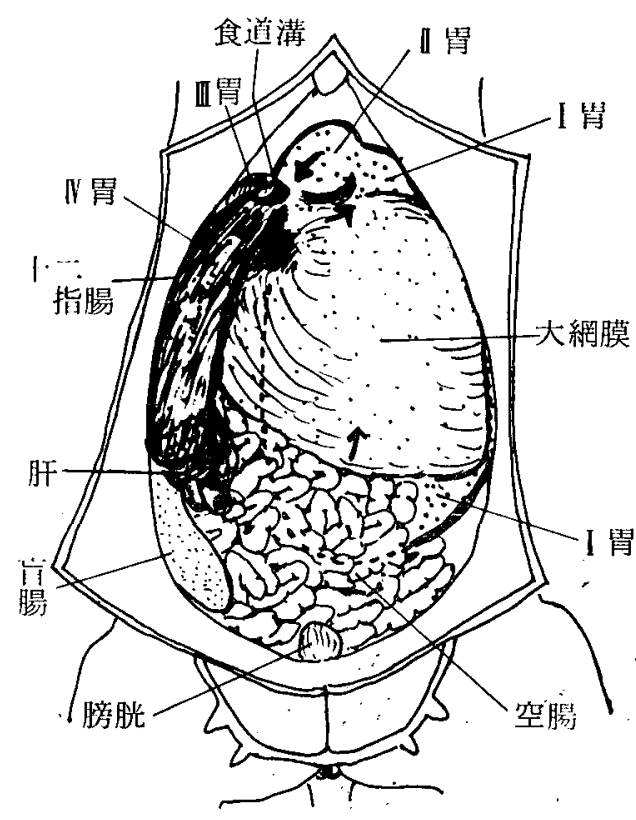

図 2. 代胃右方変位・脂肪壊死の模式図

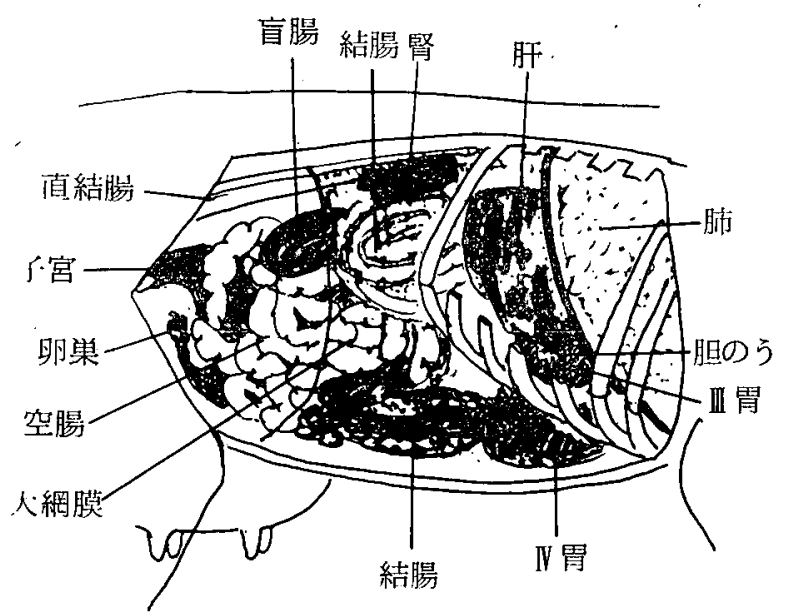

図3. N 胃左方变位のローリングによって 腸閉塞存発した模式図
膜間部に迂曲変位をしていた。第四胃は右方 に変位して臌大し, 内容物充満し，ガスの貯 溜は少なく，食道溝を中心に第三胃と第四胃 の軸転がみられ，網膜の前方第四胃，十二指 腸および萃臓の部分に脂肪壊死塊, 腸円盤部 の脂肪壊死が触知できた变位症例群であり， 第四胃切開によって内容物を除去し，変位部 を整復したととろ 5.11 治瘾の転帰をとった。

D）症例№37は, 昭 49.8 生。55.4. 3 分婏し 55 . 4. 5 発病した。 4.5 初診時ケトーシスの治療 を行なったが，4.10第四胃左方変位が確認さ れたので，ローリング法により整復を行った ところ，数時間にして疝痛症状を呈した。よ って同日腸閉塞のもとに開腹手術を行ったと てろ，図 3 に示すような所見であった。すなわ ち，子宮と空腸及び結腸が交叉回転し，腸間 膜根懸垂靶帯の軸転をなし，大網膜は前方に 波状移動弛緩し，前方に脂肪壊死が触知され， 正常位には復しておらず，第四胃左方变位は 整復されていたが，腸閉塞捻転を発来したも ので，第一胃は縮小し内容は水分欠乏の状態 支呈していた。本症例のように複雑な変位症 候群においては，ローリング法による整復は 検討を要するものである。

E）症例 No45 は, 昭 48.10 .30 生。55.3.28 分婏したが，起立不能のため上診した。過肥 にして食欲・反すう廃絶， T $39.0 ， \mathrm{P} 120$, $\mathrm{R} 60$, 呼吸促迫, 排荼なし, 後軀知覚鈍麻, 起立不能, 胃腸䆭動停止, 心音不正, 肺胞音 粗癘，直腸内に宿粪なく，脂肪壊死塊を触知 す。血液及び尿の生化学的所見を表 3 亿示し た。3.28の所見では白血球数は $9.700, \mathrm{Ht}$ 値 
は $43 \%$ で増加し, $\mathrm{Hb}$ 量は $8.7 \%$ と减少, 血糖は $78.50 \mathrm{mg} / d \ell$, コレステロールは $130.0 \mathrm{mg} / d \ell$ と高く,

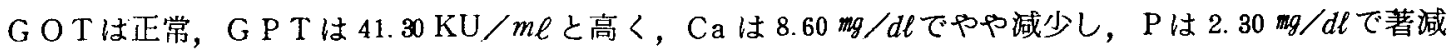

表 3. 血液, 尿の生化学的所見

\begin{tabular}{|c|c|c|c|c|c|}
\hline 成 分 & 月 日 & $3 / 28$ & $3 / 29$ & $3 / 30$ & $3 / / 31$ \\
\hline W B C & & 9. 700 & 11,800 & 6,900 & 7,500 \\
\hline $\mathrm{H} \mathrm{t}$ & $(\%)$ & 43.00 & 38.00 & 37.00 & 45.00 \\
\hline 血 糖 & $(m g / d \ell)$ & 78.50 & 78.87 & 82. 71 & 22.54 \\
\hline コレステロール & $L(")$ & 130.00 & 72.55 & 89. 40 & 88.20 \\
\hline GOT & $(\mathrm{KU} / m \ell)$ & 83.50 & 143.80 & 378.70 & 571.70 \\
\hline GP T & $(" \prime)$ & 41. 30 & 54. 94 & 48.82 & 75.78 \\
\hline $\mathrm{Ca}$ & $(m g / d \ell)$ & 8.60 & 9. 12 & 11.40 & 8. 12 \\
\hline $\mathrm{P}$ & $(\prime \prime)$ & 2. 30 & 2.75 & 9.00 & 6. 42 \\
\hline $\mathrm{TP}$ & $(g / d \ell)$ & 6.05 & 6.09 & 6. 39 & 6. 46 \\
\hline アルブミン & $(" \prime)$ & 3.53 & 3.58 & 3.37 & 3. 94 \\
\hline $\mathrm{LDH}$ & $(\mathrm{b} / m \ell)$ & 2,815 & 2,857 & 3,613 & 3,241 \\
\hline$B U N$ & $(m g / d \ell)$ & 9. 81 & 10.90 & 13. 18 & 8. 76 \\
\hline $\mathrm{Hb}$ & $(\%)$ & 8.70 & 8. 31 & 13.12 & 15.15 \\
\hline 尿 $\mathrm{pH}$ & & 6.8 & 6.6 & 6.6 & 7. 0 \\
\hline 尿 蛋白 & & $\mathrm{HH}$ & HH & H & H \\
\hline
\end{tabular}

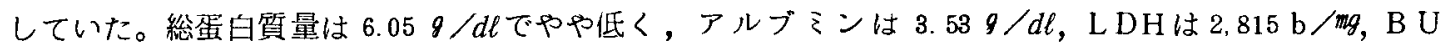

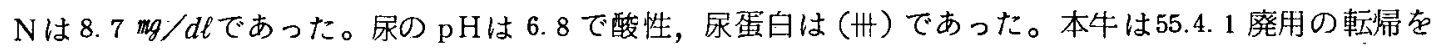
とったが，3.31 までの 3 回の血液および尿所見について, 特に変化した項目を見ると, 血糖は 3.31 で $22.54 \mathrm{mg} / \mathrm{d} \ell$ と著減し，G O T およびG P T は著增し，Hb 量は增加している。尿は酸性にして尿蛋白を 排泄していることは，初猃時から好転していない所見であった。剖検所見では，第一胃は縮小して大網 膜の前方に移動し，波状解壁をなし，アコーデオン様に弛緩し，大網膜，十二指腸，第四胃および脺 部に膨大な脂肪壊死, 腸間膜脂肪壊死, 肝脂肪変性, 腎出血, 腎周囲の脂肪壊死, 第四罥食滞漬瘍, 第 三胃水分欠乏, 空腸 左方変位, 盲腸便秘が認められた。本症の起立不能は，C a および P の減少に起因 したものではなく, 腸間膜根部の軸転と腸の変位, 脂肪壊死塊などのため, 大網膜の分婏後元に復しき れず，一連の変位症候群に上る起立不能であると思考された。

F）症例 Na 51 は，鹏 48.3.27生，55.4.20 分娩し，55.4.21 発病。子宮全脱し起立不能のため診療する。 4.22正常に復するも，4.25急性乳房炎を発し起立困難となる。4.28乳房炎好転するも起立不能にして，

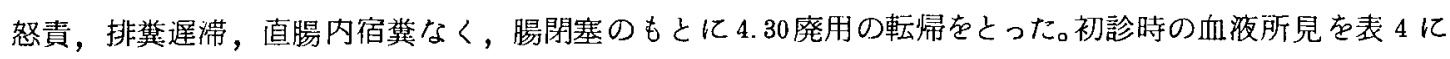
示した。 $\mathrm{Ht}$ 值は $41 \%$ で高く, $\mathrm{Hb}$ 量は $13.8 \mathrm{~g} / \mathrm{dl}$ でやや高く, 白血球数は 14,800 で増加していた。 $\mathrm{Ca}$ 値は $5.64 \mathrm{mg} / \mathrm{d} \ell$ で減少し, Pは $4.19 \mathrm{mg} / \mathrm{d} \ell$ でやや減少, GOTは $114.3 \mathrm{KU} / \mathrm{m} \ell$ で高く, GPTは正常，L $\mathrm{DH}$ 正常, 皿糖は $42.5 \mathrm{mg} / d \ell$ で正常, 総コレステロールは $63.05 \mathrm{mg} / d \ell て ゙$ 低く, 総蛋白質量は $6.238 / d \ell$,

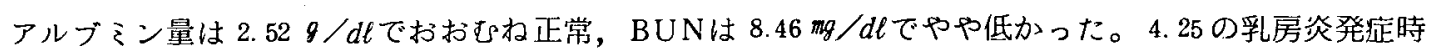


表 4. 血液検查所見

\begin{tabular}{|c|c|c|c|c|}
\hline \multicolumn{2}{|c|}{ 月 $\quad$ 日 } & $4 / 21$ & $4 / 25$ & $4 / 29$ \\
\hline $\mathrm{Ht}$ & $(\%)$ & 41.00 & 37.00 & 30.00 \\
\hline $\mathrm{Hb}$ & $(\%)$ & 13. 84 & 12. 51 & 11.95 \\
\hline WBC & & 14,800 & 2,300 & 2,700 \\
\hline $\mathrm{Ca}$ & $(m g / d \ell)$ & 5.64 & 8,60 & 6. 19 \\
\hline $\mathrm{P}$ & $(11)$ & 4. 19 & 7. 68 & 7. 87 \\
\hline GOT & $(\mathrm{KU} / \mathrm{m} \ell)$ & 114. 30 & 324.40 & 898.80 \\
\hline GOP & $(1 /)$ & 21.92 & 42.55 & 112. 20 \\
\hline LDH & $(\mathrm{b} / m \ell)$ & 2,519 & 3,774 & 3,994 \\
\hline$G l u$ & $(m g / d l)$ & 42.54 & 57. 24 & 103. 90 \\
\hline Chol & $(11)$ & 63.05 & 102. 30 & 53.08 \\
\hline T.P. & $(g / d \ell)$ & 6.32 & 5.84 & 5. 26 \\
\hline $\mathrm{Alb}$ & $(11)$ & 2. 52 & 2.04 & 2. 28 \\
\hline BUN & $(m g / d l)$ & 8.46 & 17. 80 & 13. 46 \\
\hline 主 & 徵 & 子宮脱起立不能 & 乳 房 资 & 起立不能腸閉塞 \\
\hline
\end{tabular}

には，前者に比して白血球数は著しく減少して 2,300であり,敗血症様の所見を呈していた。GOT,GPT およびLIH活性值は增加し, 総蛋白㬅量は娍少して $5.84 \mathrm{~g} / \mathrm{d} \ell, \mathrm{BUN}$ は $17.80 \mathrm{mg} / \mathrm{d} \ell$ と著增していた。

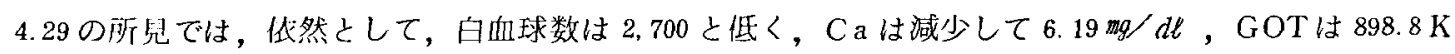
$\mathrm{U} / m \ell, \mathrm{GPT} は 112.2 \mathrm{KU} / m \ell$ と著增し, 総コレステロールは $53.08 \mathrm{mg} / d \ell$ と減少, 総蛋白質量は5.26 \& $/ d \ell, ア ル フ ゙ ミ ン は 2.28 \mathrm{~g} / d \ell$ と減少していた。腸閉塞および腹膜炎を疑い廃用転帰とした。剖検するに, 大網膜の前方移動, 腹水過多, 第四胃右方変位, 出血, 第三胃の著しい水分欠云, 大網膜前方及び膵に

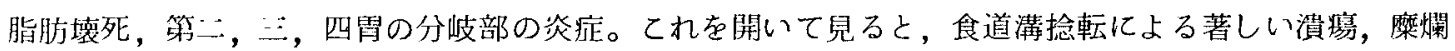
および出血が見られ，食糜の通過が困難であったというととが確誑できた。

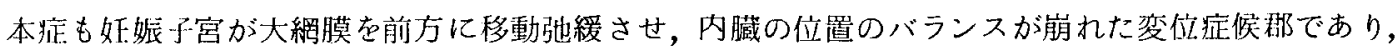
腹膜炎および起立不能をきたした症例であった。

\section{考察並びに要約}

瘀例 58 頭の内臓変位について要約すれば,

（1）乳牛は一般に日管大麦，トウモロコシなどの款類多給により，分婏啲は過肥状態にして，特に中 軀の深みに众けているのが，一つの条件をなしていると思われる。平罒(5)，赫ら(1)，多部田ら(6)は， 第阳胃の变什は多頭化現象にともなう粗飼料不足による籍一霄容積の絔小とし，弘(7)は盲腸拡脹症につ いて，31〜 40 頭飼育規模のものに発生が多く，同一牛舎で多発が見られ，3 頭以上発生した牛舎が $19 \%$

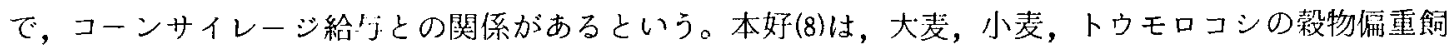

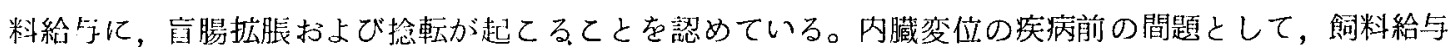
の条件も装团となる。

(2) 次に奼娠と分娩という条件も要因となる。妊娠は月令がたつにつれて，子宮が臌大化し，然も大 網膜の内部に定着し, 腸と共存し，大網膜は脂肪蓄積して肥厚し，膨大な妊娠子宮とで，第一胃と腸は 前方に抑圧され，押し上げられる。大網膜は可動性で第四青，肝，腸円盤などと結着し，大網膜が移動 すれば，第四胃も移動しゃすい状態となりうる。大網内で子宮が膨張していくと，腸も可動的であるた め，特に空腸，回腸，盲腸の部分は，住み家を失なったように，子宮から追たてられ網膜外に移動する。 
第一胃は唼大な子宮や網膜及び腸間膜の厚い脂肪層に圧迫をうけて縮小し，粗飼料の食い込が少くなる。 森ら(3)は妊娠後半の子宮重量と, 分婏のストレスが変位と関係し, 第一胃が機能低下して第四胃に異常 醊酵が起てるためと考えている。更に第一胃は81例中58例が癒着し，第一胃を上方に吊り上げているた め間陌ができて, 第四胃が変位するというが, 我々の症例では, 第一胃の癒着は見受けられなかっ た。変位は分婏後多発する傾向からして, 胎児の過大, 難産および助産の失宜なども関与しているので はないかと考えられる。

（3）変位は飼料やストレスで起てるものとするなら，妊娠分婏にかかわらず，もっと発生しても不思

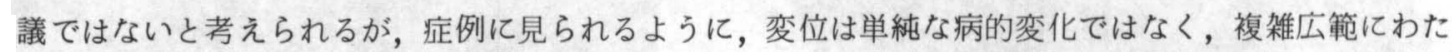
った変化を呈するので，外園ら(9)がいうように変位症候郡として取扱うのがぴったりすると思われる。 例えば第四胃の左方変化にしても，右方変位にしても，再発する場合が見受けられる点から考えても， 第四胃のみの整復を考虑して, 網膜や腸の変化を検討しなければならないし, 右方変位の場合は左方変 位に比し, 症状が重く, 腹腔内の変位も, 組織の障害の程度も強いので尚更に考慮する必要がある。右 方変位と腸の病変が重なっていたり, 或いは食道溝の揄転などが附随していると急死の転帰をとる場合 もあるので慎重に対処することが大切である。

(4) 更に腹腔内圧も要因として関与しているものと考えられる。妊娠した膨大なる子宮が，たちまち 容積を縮小し子宮が殆んど整復される頃に変位が起こる点から考えて, 腹腔内圧が急速に陰圧に変化す るので, 分婏後の変化した内臓が元に復しきれないのではないかと考えられる。更に弛緩した厚い脂肪 層をおびた大網膜は，第二・四胃部に重い脂肪壊死塊をかっえていれば，重石のような役割となって， かえって元に復しきれず，又弛緩した大網膜からはみ出された腸は，運動が悪ければ尚更に，元に復す ることは困難となり, 第一胃は容積が縮小し, 腹筋は拡張し弛緩しており, 分婏後も容易に元に腹しき れず, 腹腔内圧は陰圧が高まっていると考えてよいと思う。膁部は特に陥凹し，開復手術時において， 腹膜に創孔を開けると，空気が勢よく腹腔に流れ込む事実から明らかである。外園ら (9)も腹腔内圧の変 化を起こし易い妊娠および分婏に関係ありとし分婏と腹腔陰圧を見逃すととはできない。

(5) 変位症候郡は, 腹腔内器官の弛絠, 移動, 変位, 軸転, 捻転, 回転などにより, 血行障害, 神経 麻疸, 炎症が附随して起る一連の複雑な症候群と考えても間違いでないと思う。木全は(9)第四胃迷走神 経麻瘏説を主張し，また消化器官全体のアトニーは，第四胃の変化を生じやすいという。腸間膜根の腸 懸垂靱帯が軸転すると, 血管や内臟神経を圧迫し, 血行障害, 胃腸の運動や機能障害を起とし, 緊張や 弛緩現象をともなういろいろな変化の組合せ，或いは障害変化の部位によって，症状や病性に差が生じ， 病変は原因が長期にわたり, 然も局部的病変でなく広範に変化が起てり，複雑性を呈することになるの で, 育成を含め, 妊娠中の飼養管理が重要であると考える。

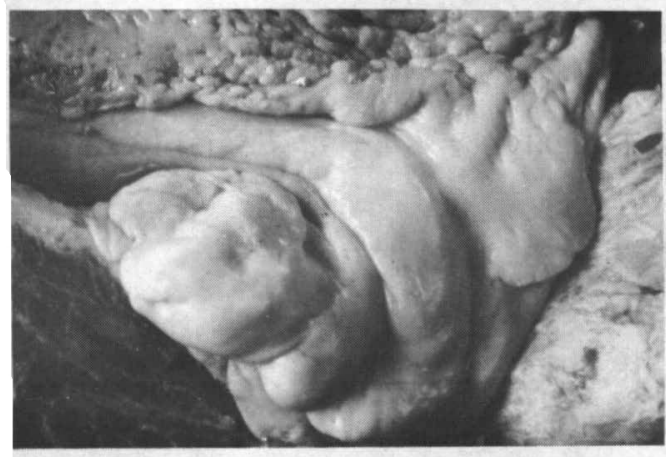

症例 No. 45

大網膜・腸間膜の脂肪壊死を示す

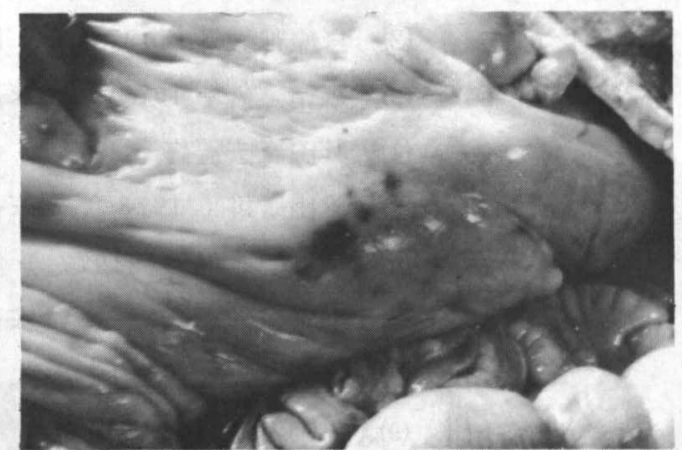

大網膜を前方にめくり上げると，網膜の出血， 結腸便秘がみられ, 第一胃は容積縮小している 


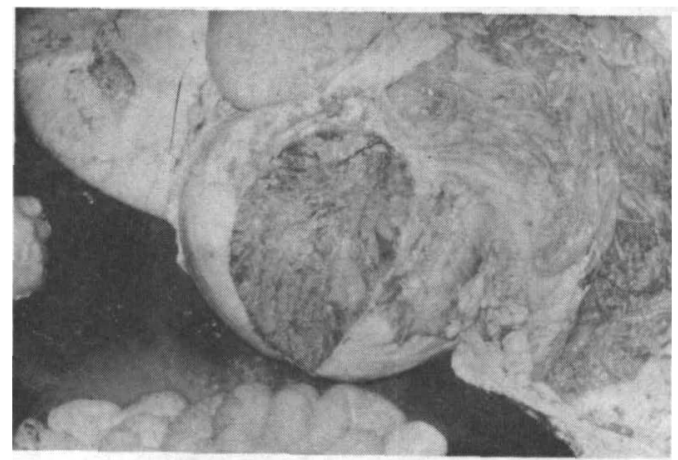

第四胃の壊演及び第三胃の便秘を示す。

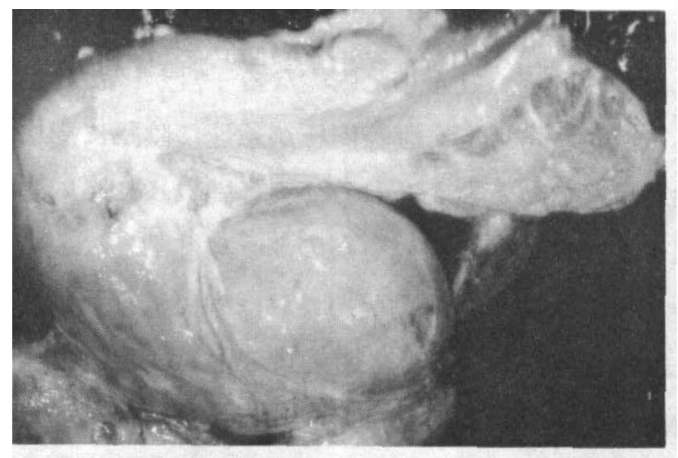

第四胃・第二胃部に出血・炎症が見ら れ, 第三胃は便秘 (食滞)している。

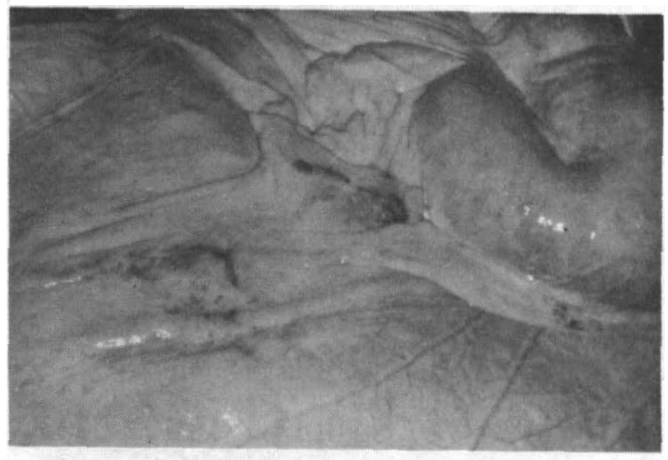

\section{症例 No 51}

大網膜前方に脂肪壊死と出血があり，第四 胃の膨満・揄転が見られる。

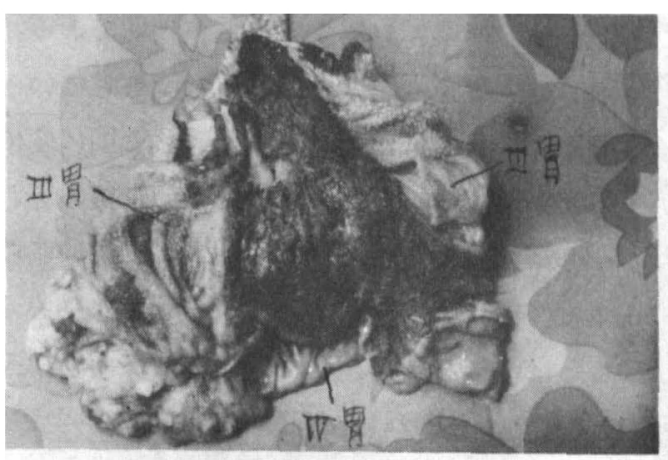

食道溝部を開いて見ると, 粘膜の潰 瘍・壊死・出血・糜爛が見られる。

参考文献

（1）赤松万義（1975） 家畜診療, 140:33.

（2）宮原雅教外（1977） 日獣会誌, 30:430

（3）森靖之外（1978） 家畜診療, 170:32.

(4) 其田三夫監修（1978） 牛の臨床 P 210 , デイリーマン社発行

(5) 平田敏雄 ( 1978 ) 家畜診療, $178: 3$.

(6) 多部田兼弘外 ( 1977) 家畜診療, 168:27.

(7) 弘雅信 $(1980)$ 家畜診療, 200: 41 .

（8）其田三夫監修（1978） 牛の臨床 P 250, ディリーマン社発行

(9) 外園孝二外 $(1975)$ 家畜診祭, $140: 23$. 